\title{
Pengaruh Kepatuhan Latihan Senam Kesegaran Jasmani 1988 Terhadap Perilaku Anak dengan Gangguan Pemusatan Perhatian/Hiperaktivitas
}

\author{
Listya Tresnanti Mirtha, ${ }^{*}$ Rini Sekartini** \\ "Program Studi Ilmu Kedokteran Olahraga Departemen Ilmu Kedokteran Komunitas, **Departemen Ilmu Kesehatan Anak Fakultas \\ Kedokteran Universitas Indonesia
}

Latar belakang. Gangguan Pemusatan Perhatian/Hiperaktivitas (GPP/H) merupakan gangguan neuropsikiatrik yang disinyalir memberikan dampak negatif bagi kesehatan ketika dewasa.

Tujuan. Penelitian ini dilakukan untuk mengetahui karakteristik fisik dan sosiodemografis anak dengan GPP/H, dan pengaruh kepatuhan latihan fisik terhadap perubahan prilaku pada anak GPP/H.

Metode. Penelitian eksperimen, pre-post design dengan perlakuan latihan SKJ ' 88 dilakukan pada subjek penelitian di Sekolah Khusus Al-Ikhsan selama 8 minggu. Pemilihan sampel digunakan metode tanpa acak (non probability sampling) dengan jenis metode consecutive sampling, yaitu semua anak dengan GPP/H yang memenuhi kriteria pemilihan akan diikutsertakan dalam penelitian. Analisis data digunakan uji t satu sampel dan uji t berpasangan.

Hasil. Di antara 40 subjek penelitian, didapatkan 19 (47,5\%) sangat patuh dan 21 (52.5\%) patuh. Nilai selisih rata-rata skor SPPAHI orangtua (SPPAHI-O) tiap tipe GPP/H didapatkan inatentif 46,2 ( $<<0,001$ ), hiperaktif-impulsif 60,4 ( $<<0,001$ ), campuran 47,6 $(\mathrm{p}<0,001)$ ditunjukkan adanya perbaikan perilaku di rumah. Nilai selisih rata-rata skor SPPAHI guru (SPPAHI-G) tiap tipe GPP/H didapatkan inatentif 41,7 ( $\mathrm{p}<0,001)$, hiperaktif-impulsif 56,8 ( $\mathrm{p}<0,001)$, campuran 42,2 ( $\mathrm{p}<0,001)$ ditunjukkan adanya perbaikan perilaku di sekolah.

Kesimpulan. Hasil penelitian menunjukkan kepatuhan melakukan latihan SKJ '88 berpengaruh terhadap perbaikan perilaku di rumah $(\mathrm{p}<0.001)$ dan di sekolah $(\mathrm{p}<0.001)$ pada kelompok subjek sangat patuh maupun patuh. Sari Pediatri 2016;18(2):146-56

Kata kunci: anak dengan GPP/H, latihan fisik, perilaku

\section{The Influence of Exercise on Behaviours Improvement in Children with Attention-Deficit/Hyperactivity Disorder}

Listya Tresnanti Mirtha, Rini Sekartini*

Background. Attention-Deficit/Hyperactivity Disorder (ADHD) is a neuropsychiatric disorder in children that allegedly affect their health in adulthood.

Objective. This research was aimed to find physical characteristic and sociodemography of the children of ADHD and to know the influence of exercise due to changes of behaviour children with ADHD.

Methods. This study was experimental research with pre and post design by giving SKJ ' 88 excercise to the subject of study at Sekolah Khusus Al-Ikhsan for 8 weeks. Sample selection was done without random (nonprobability sampling) with consecutive sampling method types, all children with ADHD who met the selection criteria will be included in the study. The analysis of data used one sample $\mathrm{t}$ test and paired t test.

Results. Total subject were 40 subjects. 19 (47.5\%) very comply and 21 (52.5\%) comply. Obtained difference value average score SPPAHI parent (SPPAHI-O) for each type of ADHD: inattentive 46,2 ( $\mathrm{p}<0,001$ ), hyperactivity-impulsivity 60,4 ( $<<0,001)$, mix 47,6 $(\mathrm{p}<0,001)$ showed improved behavior at home. Obtained difference value average score SPPAHI teacher (SPPAHI-G) each type ADHD: inattentive 41.7 ( $\mathrm{p}<0.001)$, hyperactivity-impulsivity 56.8 ( $\mathrm{p}<0.001)$, mix $42.2(\mathrm{p}<0.001)$ showed improved behavior at school. Conclusion. Result from this study show that complience doing SKJ '88 excercise influenced improvement of behaviour at home $(\mathrm{p}<0.001)$ and school $(\mathrm{p}<0.001)$ in both very comply and comply group. Sari Pediatri 2016;18(2):146-56

Keywords: children with ADHD, physical exercise, behaviour

\footnotetext{
Alamat korespondensi: Dr. Listya Tresnanti Mirtha, SpKO. Program Studi Ilmu Kedokteran Olahraga, Departemen Ilmu Kedokteran Komunitas,
} Fakultas Kedokteran Universitas Indonesia. Email: tresnanti.listya@ui.ac.id 
G angguan pemusatan perhatian/hiperaktivitas $(\mathrm{GPP} / \mathrm{H})$ adalah suatu kelainan neurobehavioral kronis yang mengganggu kemampuan seseorang untuk melakukan inhibisi perilaku, yang berfungsi secara efisien dalam aktivitas yang berorientasi pada tujuan, atau melakukan regulasi tingkat aktivitas yang sesuai dengan tahapan perkembangannya. Gangguan inhibisi perilaku disebut impulsivitas, ketidakmampuan berfungsi secara efisien untuk memenuhi suatu tujuan disebut inatensi, dan kegagalan regulasi tingkat aktivitas dikenal sebagai hiperaktivitas. ${ }^{1}$

Berdasarkan data dari American Psychiatric Association (APA), keadaan ini merupakan gangguan psikiatrik terbanyak pada anak dengan insiden 3\%-5\% pada anak usia sekolah, dan dapat menetap hingga masa dewasa. ${ }^{2}$ Saputro, ${ }^{3}$ berdasarkan diagnostic and statistic manual for mental disorder IV (DSM-IV), prevalensi untuk tipe hiperaktif-impulsif $2,2 \%$, tipe campuran hiperaktif-impulsif dan inatentif $5,3 \%$, tipe inatentif $15,3 \%$. Di Indonesia, angka kejadiannya masih belum pasti, tetapi cukup banyak dan semakin meningkat. Tanjung menyebutkan bahwa prevalensi anak dengan GPP/H telah mencapai 4,2\% pada anak sekolah dasar kelas I-III di Jakarta Pusat. ${ }^{4}$ Di berbagai negara di dunia saat ini, prevalensi anak dengan GPP/H sudah mencapai sekitar 3\%-11\%.6,7

Gangguan ditandai dengan ketidakmampuan anak memusatkan perhatian pada suatu objek sehingga rentang perhatian terjadi sangat singkat dibandingkan anak lain seusianya. Selain itu, gangguan ini biasanya disertai dengan gejala hiperaktif dan perilaku impulsif, yang akhirnya dapat mengganggu perkembangan kognitif, perilaku, sosialisasi, maupun komunikasi. ${ }^{8,5,3}$ Gangguan pemusatan perhatian dan hiperaktivitas adalah gangguan perkembangan dengan onset gejala sebelum usia 7 tahun. $^{9}$

Beberapa penelitian menyebutkan bahwa masalah agresi dan perilaku di masa kanak-kanak merupakan prediksi menetapnya GPP/H di kehidupan remaja dan dewasa muda, tetapi relatif sedikit yang diketahui mengenai faktor risiko yang menentukan perkembangan GPP/H. ${ }^{3,7,8}$ Gejala inatensi maupun hiperaktivitasimpulsivitas menurun sekitar 50\% setiap 5 tahun antara usia 10 hingga 25 tahun. Hiperaktivitas sendiri menurun lebih cepat ketimbang impulsivitas dan inatensi. ${ }^{10}$

Aktivitas fisik anak tentunya meliputi kegiatan sehari-hari di berbagai tempat, baik di rumah maupun di sekolah. Aktivitas fisik tersebut adalah suatu bentuk aktivitas otot yang akan menghasilkan jumlah pengeluaran energi sebanding dengan kerja otot, ${ }^{11}$ sedangkan latihan fisik adalah aktivitas fisik yang terencana, terstruktur, dilakukan berulang, dan mempunyai tujuan tertentu, baik untuk meningkatkan maupun memelihara kesehatan dan kebugaran jasmani. ${ }^{12,13}$. Anak yang aktif berpartisipasi dalam latihan fisik akan membuatnya lebih bugar, kuat, dan sehat. Kebugaran jasmani akan menjadi dasar kesehatan anak di masa dewasa nanti. dan diharapkan kebiasaan hidup sehat akan terus terpelihara sampai dewasa. ${ }^{12,13}$ Beberapa bukti menunjukkan bahwa semakin sering aktivitas fisik dilakukan anak maka akan memberikan perbaikan pada sistem muskuloskeletal, komposisi tubuh, dan kesehatan kardiorespirasi. Selain itu, aktivitas fisik yang dilakukan oleh anak usia sekolah mempunyai keuntungan, seperti perbaikan pada profil lipid, tekanan darah, persepsi diri, gejala kecemasan dan depresi, serta kemampuan akademik. ${ }^{12}$

Flemming dan Taylor ${ }^{14}$ menyebutkan bahwa pengaturan program pelatihan aktivitas gerak tubuh dengan baik di sekolah merupakan salah satu subjek penting di dalam kurikulum. Retno ${ }^{15}$ melaporkan bahwa SKJ '88 terbukti dapat meningkatkan kebugaran jasmani dalam waktu 6 minggu, pelaksanaan terbagi dalam 3 kali setiap minggu, dan tidak ada perbedaan yang bermakna antara SKJ '84 dan SKJ '88 dalam meningkatkan kebugaran jasmani siswa putra SMA di Salatiga. Suaeb juga melaporkan hasil bahwa SKJ '88 terbukti meningkatkan kebugaran jasmani siswa kelas II dan III SMP di Jakarta Barat dalam waktu 8 minggu, pelaksanaan terbagi dalam 3 kali setiap minggu. ${ }^{16}$

Salah satu bentuk terapi non medikamentosa pada anak dengan GPP/H adalah dengan pendekatan modifikasi terapi perilaku dan bermain yang diikuti dengan irama gerakan yang ritmis. Ditinjau dari karakteristiknya, latihan SKJ '88 merupakan latihan daya tahan kardiorespirasi yang terdiri atas komponen gerakan yang sederhana, mudah dicontohkan, dan diikuti oleh siapapun, dinamis, riang, aman, serta diiringi musik di dalam pelaksanaannya. Dengan dasar pemikiran inilah latihan SKJ '88 sebagai salah satu model latihan daya tahan kardiorespirasi diharapkan dapat memberikan manfaat positif apabila dilakukan oleh anak dengan GPP/H karena menggabungkan unsur bergerak, berlatih, bermain, dan musik dalam pelaksanaannya. Penelitian ini dilakukan untuk mengetahui karaktereristik fisik dan sosiodemografis anak dengan $\mathrm{GPP} / \mathrm{H}$, pengaruh kepatuhan melakukan 
latihan fisik terhadap perubahan prilaku pada anak $\mathrm{GPP} / \mathrm{H}$.

\section{Metode}

Penelitian rancang penelitian eksperimen, yaitu pre-post design, dengan perlakuan pemberian latihan SKJ '88 pada subjek penelitian. ${ }^{1,2}$ Penelitian dilaksanakan di Sekolah Khusus Al-Ihsan Tangerang selama 8 minggu, dimulai sejak tanggal 31 Oktober 2011 sampai dengan tanggal 23 Desember 2011. Subjek yang diteliti adalah subjek yang mengikuti penelitian sampai selesai. ${ }^{1,2}$ Kepatuhan latihan adalah kesanggupan seorang anak untuk datang dan melakukan latihan fisik dengan benar di sekolah. Tolok ukur yang digunakan adalah jumlah absensi kehadiran anak dan kemampulaksanaan anak mengikuti latihan SKJ '88. Pengisian formulir dilakukan oleh instruktur yang bertugas. Jumlah kehadiran dinilai dari pencatatan absensi kehadiran, sedangkan penilaian saat melakukan latihan fisik dilakukan dengan acuan daftar tilik.

Tingkat kepatuhan latihan SKJ '88 dikelompokkan menjadi kelompok tidak patuh dan patuh. Namun, terjadi ketidaksesuaian saat penelitian berlangsung, kami melakukan penyesuaian kembali dengan nilai cut-off berdasarkan distribusi data sehingga pengelompokan menjadi patuh dan sangat patuh. Patuh apabila kehadiran kurang dari nilai cut-off total kehadiran pelaksanaan yang baru dan skor total pada daftar tilik penilaian pelaksanaan SKJ '88 selama periode 8 minggu kurang dari nilai cut-offyang baru. Sangat patuh apabila kehadiran lebih dari atau sama dengan nilai cut-off total kehadiran pelaksanaan yang baru dan skor total pada daftar tilik penilaian pelaksanaan SKJ '88 selama periode 8 minggu lebih dari atau sama dengan nilai cut-off yang baru.

Skala Penilaian Perilaku Anak Hiperaktif Indonesia (SPPAHI) adalah daftar tilik yang berisi gejala klinis GPP/H pada anak usia 6-12 tahun yang dapat digunakan oleh dokter, guru, dan orang tua. Berisi 35 butir pernyataan yang dikembangkan oleh Dr. dr. Dwijo Saputro, $\operatorname{SpKJ}(\mathrm{K})$. Terdiri dari dua sub-skala, yaitu sub-skala tidak mampu memusatkan perhatian/inatensi (nomor 1, 3, 4, 5, 6, 8, 9, 10, 16, 18, 19, 20, 21, 22, $23,25,26,27,33,35)$ dan sub-skala hiperaktivitasimpulsivitas (nomor 2, 11, 12, 13, 14, 15, 24, 28, $29,30,32,34){ }^{2,16}$ SPPAHI digunakan untuk menilai perubahan perilaku anak.
Pemilihan sampel dilakukan dengan metode tanpa acak (non probability sampling) dengan jenis metode consecutive sampling, yaitu semua anak dengan GPP/H yang memenuhi kriteria pemilihan akan diikutsertakan dalam penelitian. ${ }^{1}$ Kriteria inklusi yang digunakan terdiri atas (a) anak laki-laki dan perempuan berusia 6-12 tahun, (b) didiagnosis GPP/H oleh dokter, (c) merupakan siswa Sekolah Khusus Al-Ihsan pada tahun ajaran 2011/2012, (d) tidak menggunakan obat untuk GPP/H minimal satu bulan terakhir, (e) tidak terlibat dalam kegiatan olahraga berstruktur, (f) mengikuti kegiatan olahraga secara rutin kurang dari 3 kali dalam seminggu ( $<3 \mathrm{x} / \mathrm{minggu}$ ), (g) tidak ada kontra indikasi melakukan latihan fisik, (h) orangtua menyetujui dan menandatangani lembar persetujuan (informed consent). Kriteria eksklusi terdiri atas (a) anak dengan GPP/H yang mengalami cedera muskuloskeletal atau perburukan gejala yang lain yang merupakan kontra indikasi dilakukannya latihan fisik, (b) orang tua tidak bersedia apabila anaknya mengikuti penelitian. Besar sampel yang digunakan pada penelitian dihitung dengan rumus besar sampel untuk penelitian analitik numerik berpasangan dan diperoleh hasil 34 orang. Drop out dilakukan apabila dalam perjalanan subjek penelitian mengalami cedera muskuloskeletal dan orang tua tidak bersedia apabila anaknya melanjutkan penelitian. Untuk mengantisipasi kemungkinan terjadinya drop out diperlukan tambahan sejumlah $15 \%$ dari hasil perhitungan sampel, yaitu sebesar 5 orang. ${ }^{1,2}$ Dengan demikian, besar sampel minimal yang dibutuhkan adalah 39 orang. Namun, besar sampel yang digunakan adalah sejumlah populasi terjangkau yang telah memenuhi kriteria pemilihan.

Penelitian ini merupakan penelitian lapangan yang terdiri dari 3 tahap pemeriksaan. (1) Pemeriksaan tahap I $\left(\mathrm{O}_{1}\right)$, merupakan pemeriksaan sebelum anak melakukan latihan fisik, meliputi pengisian formulir penelitian dan data tentang aktivitas fisik oleh orangtua, skoring akhir terhadap jumlah aktivitas fisik yang dilakukan oleh dokter peneliti, pengisian daftar tilik Skala Penilaian Perilaku Anak Hiperaktif Indonesia (SPPAHI) oleh orangtua dan guru. Daftar tilik SPPAHI digunakan untuk memantau perkembangan gejala klinis GPP/H yang dinilai dari waktu ke waktu. Penentuan skor akhir daftar tilik SPPAHI dilakukan oleh dokter peneliti. Pengisian daftar tilik kriteria diagnosis GPP/H DSMIV TR untuk menentukan tipe GPP/H oleh dokter spesialis anak. Pemeriksaan status fisik dan tumbuh kembang motorik anak oleh dokter peneliti dibantu 
oleh petugas medis. (2) Pemeriksaan tahap II $\left(\mathrm{O}_{2}\right)$, yang merupakan periode pemeriksaan selama anak diharuskan melakukan latihan SKJ '88 dengan durasi 8 menit 38 detik, yang dilakukan dalam 2 sesi latihan dalam sehari di sekolah (setiap sebelum dimulai pelajaran di sekolah dan sebelum pulang ke rumah), 5 hari dalam seminggu. Tujuannya untuk menilai kepatuhan (kehadiran dan kemampulaksanaan) melakukan latihan SKJ '88 dan perilaku subjek penelitian selama masa pemberian perlakuan. Dalam periode 8 minggu ini dilakukan evaluasi berupa perbaikan gejala klinis berdasarkan pengisian daftar tilik SPPAHI oleh orang tua dan guru dan pencatatan keluhan-keluhan lain yang mungkin timbul. (3) Pemeriksaan tahap III $\left(\mathrm{O}_{3}\right)$, merupakan pemeriksaan akhir anak setelah melakukan latihan SKJ '88 selama periode 8 minggu. Pemeriksaan yang dilakukan adalah pemeriksaan perbaikan gejala klinis berdasarkan pengisian daftar tilik SPPAHI oleh orangtua dan guru dengan dilakukan evaluasi ulang yakni anamnesis kembali anak dan orangtua.

Data dianalisis untuk mengetahui karakteristik fisik dan sosiodemografis subjek penelitian, berdasarkan nilai rerata dan simpang baku, disajikan dalam bentuk tabular dan tekstular, disesuaikan dengan skala dan distribusi data. Rekapitulasi data kepatuhan melakukan SKJ '88 dan analisis indikator kepatuhan menggunakan uji t satu sampel (one-sample $t$ test). Analisis untuk mengetahui perbedaan perilaku subjek penelitian antara sebelum dan sesudah perlakuan dilakukan dengan uji t berpasangan (paired samples $t$ test). Uji normalitas dilakukan dengan uji Shapiro Wilk, oleh karena jumlah subjek penelitian kurang dari 50. Batasan nilai $\mathrm{p}<0,05$ dianggap bermakna secara statistik. Pada tahap akhir dilakukan uji anova untuk membandingkan perubahan perilaku pada kelompok subjek sangat patuh dan patuh di setiap tahap penilaian, serta melakukan analisis post hoc Bonferroni untuk mengetahui pengaruh kepatuhan melakukan latihan SKJ '88 terhadap perubahan perilaku subjek sesudah perlakuan. Batasan nilai $\mathrm{p}<0,05$ dianggap bermakna secara statistik.

\section{Hasil}

Di antara 46 subjek, 6 tidak memenuhi kriteria pemilihan yang telah ditetapkan karena diagnosis GPP/H tidak dapat ditegakkan serta terkait dengan kemampulaksanaan dan keamanan subjek atas perlakuan yang akan diberikan. Dengan demikian, didapatkan 40 subjek yang diobservasi sampai dengan akhir penelitian berdasarkan protokol yang ada, selama periode 8 minggu perlakuan dan 3 kali penilaian terhadap subjek. Di antara 40 subjek 24 (60\%) laki-laki dan $16(40 \%)$ perempuan. Seluruhnya berhasil menjalani perlakuan yang diberikan sampai periode minggu ke- 8 . Berdasarkan karakteristik subjek penelitian, usia rerata laki-laki 9,5 (1.41), perempuan 10.2 (1,59). tinggi badan laki-laki 137,9 $(11,23)$, tinggi badan perempuan 136,7 (14,1). Berat badan laki-laki 38,1 $(16,80)$, berat badan perempuan $35,9(13,91)$. Indeks masa tubuh laki-laki 19,3 (5,24), perempuan 18,5 (4,23). masa lemak tubuh laki-laki $19,3(5,69)$, perempuan 18,8 $(8, .90)$. Tidak terdapat perbedaan antara subjek lakilaki dan perempuan. Data karakteristik sosiodemografis 40 subjek penelitian dibedakan berdasarkan status gizi, perkembangan motorik, tingkat aktivitas fisik, kategori aktivitas fisik, tipe GPP/H, prestasi akademik, pekerjaan orang tua, dan status ekonomi. Status gizi yang dinilai dengan kurva pertumbuhan CDC-2000 didapatkan hampir separuh subjek (18/40) berada dalam kondisi healthy weight (IMT antara persentil 5-85), sedangkan 6 berada dalam kondisi underweight (IMT kurang dari persentil 5).

Seluruh subjek berada dalam tahapan perkembangan motorik sesuai dengan tahapan usianya, dan tidak ditemukan kelainan muskuloskeletal di dalam pemeriksaan (perkembangan motorik diukur menggunakan daftar tilik). Namun, untuk aktivitas fisik yang dilakukan sehari-hari, sebagian besar subjek (39/40) termasuk dalam kategori kurang aktif (aktivitas fisik diukur menggunakan pengisian kuesioner Bouchard). Sebagian besar subjek memperlihatkan tingkat aktivitas 1-2 MET 28 (70\%). Delapan belas (45\%) subjek terdiagnosis $\mathrm{GPP} / \mathrm{H}$ tipe predominan inatentif, 5 (12.5\%) subjek dengan GPP/H predominan hiperaktif-impulsif, 17 (42.5\%) subjek dengan GPP/H tipe campuran. Berdasarkan nilai yang diperoleh pada semester terakhir, tidak ada subjek yang mempunyai prestasi akademik buruk. Sebagian besar 37 (92,5\%) anak memiliki prestasi akademik baik, $3(7,5 \%)$ orang anak mendapatkan prestasi akadmeik cukup. Proporsi pekerjaan ayah terbesar sebagai pegawai swasta (23 subjek) dan proporsi pekerjaan ibu terbesar adalah tidak bekerja (21 subjek). Sebagian besar subjek 28 (70\%) berasal dari statu ekonomi menengah.

Setelah dilakukan uji t satu sampel untuk mengetahui perbedaan kepatuhan, didapatkan nilai $\mathrm{p}<0,001$ untuk absensi kahadiran dan $\mathrm{p}<0,001$ untuk 
Listya Tresnanti Mirtha dkk: Pengaruh kepatuhan melakukan latihan SKJ 1988 terhadap GPP/H

Tabel 1. Kepatuhan subjek melakukan SKJ '88 selama 8 minggu perlakuan ( $\mathrm{n}=40)$

\begin{tabular}{lcccccccc}
\hline & Minggu & \multicolumn{2}{l}{ Nilai rerata (SB) } & \multicolumn{2}{c}{ Selisih nilai rerata (SB) } & Std. error & IK95\% & Nilai p \\
\hline Absensi kehadiran & 4 & 16,9 & $(1,98)$ & & & & & \\
& 8 & 19,5 & $(0,64)$ & 2,6 & $(1,99)$ & 0,32 & $1,91-3,19$ & $<0,001^{*}$ \\
Mampu-laksana & 4 & 53,9 & $(17,12)$ & & & & & \\
& 8 & 81,4 & $(22,14)$ & 27,5 & $(12,03)$ & 1,90 & $23,68-31,37$ & $<0,001^{*}$ \\
\hline
\end{tabular}

*uji t sampel berpasangan, berbeda bermakna pada $\alpha=0.05$

Tabel 2. Skor perilaku SPPAHI-O sebelum perlakuan sampai dengan sesudah perlakuan pada setiap tipe GPP/H ( $\mathrm{n}=40$ )

\begin{tabular}{lcccccccc}
\hline Tipe GPP/H & Minggu & \multicolumn{2}{l}{ Nilai rerata (SB) } & \multicolumn{2}{l}{ Selisih nilai rerata (SB) } & Std. error & IK 95\% & Nilai p \\
\hline Inatentif & 0 & 72,9 & $(10,17)$ & & & & & \\
& 4 & 46,7 & $(10,52)$ & 26,2 & $(10,67)$ & 2,52 & $20,86-31,47$ & $<0,001^{*}$ \\
& 4 & 46,7 & $(10,52)$ & & & & & \\
& 8 & 26,7 & $(10,4)$ & 20 & $(8,79)$ & 2,07 & $15,63-24,37$ & $<0,001^{*}$ \\
& 0 & 72,9 & $(10,17)$ & & & & & \\
& 8 & 26,7 & $(10,4)$ & 46,2 & $(14,18)$ & 3,34 & $39,12-53,22$ & $<0,001^{*}$ \\
\hline Hiperaktif- & 0 & 82,2 & $(12,58)$ & & & & & \\
impulsif & 4 & 52,4 & $(12,26)$ & 29,8 & $(18,43)$ & 8,24 & $6,92-52,69$ & $0,022^{*}$ \\
& 4 & 52,4 & $(12,26)$ & & & & & \\
& 8 & 21,8 & $(9,52)$ & 30,6 & $(6,8)$ & 3,04 & $22,15-39,05$ & $<0,001^{*}$ \\
& 0 & 82,2 & $(12,58)$ & & & & & \\
& 8 & 21,8 & $(9,52)$ & 60,4 & $(19,35)$ & 8,65 & $36,38-84,42$ & $0,002^{*}$ \\
\hline Campuran & 0 & 73 & $(12,09)$ & & & & & \\
& 4 & 51,1 & $(11,24)$ & 21,9 & $(8,29)$ & 2,01 & $17,68-26,20$ & $<0,001^{*}$ \\
& 4 & 51,1 & $(11,24)$ & & & & & \\
& 8 & 25,4 & $(6,28)$ & 25,7 & $(11,22)$ & 2,72 & $19,88-31,42$ & $<0,001^{*}$ \\
& 0 & 73 & $(12,09)$ & & & & & \\
& 8 & 25,4 & $(6,28)$ & 47,6 & $(11,26)$ & 2,73 & $41,80-53,38$ & $<0,001^{*}$ \\
\hline
\end{tabular}

* Uji annova, berbeda bermakna pada $\alpha=0,05$

kemampulaksanaan, artinya didapatkan hasil yang bermakna. Kepatuhan subjek dinilai baik secara kualitas dan kuantitas. Indikator kuantitas perlakuan adalah absensi kehadiran, sedangkan kemampulaksanaan melakukan latihan SKJ '88 merupakan indikator kualitas perlakuan. Subjek dikatakan "sangat patuh" apabila telah memenuhi kepatuhan secara kuantitas dan kualitas sehingga hanya dilakukan pengelompokan yang memuat subjek yang benar memenuhi kepatuhan secara kuantitas dan kualitas. Sebaliknya, subjek dikatakan "patuh" apabila tidak memenuhi salah satu kepatuhan.
Berdasarkan penglompokan didapatkan 19 (47\%) subjek sangat patuh dan $21(53 \%)$ patuh.

Terdapat perbedaan bermakna $(\mathrm{p}<0,001)$ pada perubahan nilai rerata skor total SPPAHI-O sebelum dan sesudah perlakuan di semua kelompok tipe GPP/H. Hanya saja pada kelompok subjek dengan tipe GPP/H predominan inatentif, selisih nilai rerata skor pada minggu kedelapan tidak sebanyak yang diperoleh pada minggu keempat. Berbeda halnya dengan kedua kelompok tipe yang lain, yang selisih nilai rerata skor pada minggu kedelapan lebih tinggi dibandingkan 
Listya Tresnanti Mirtha dkk: Pengaruh kepatuhan melakukan latihan SKJ 1988 terhadap GPP/H

Tabel 3. Skor perilaku SPPAHI-G sebelum perlakuan sampai dengan sesudah perlakuan pada setiap tipe GPP/H ( $\mathrm{n}=40)$

\begin{tabular}{|c|c|c|c|c|c|c|c|c|}
\hline \multirow{2}{*}{$\begin{array}{l}\text { Tipe GPP/H } \\
\text { Inatentif }\end{array}$} & \multirow{2}{*}{$\begin{array}{c}\text { Minggu } \\
0\end{array}$} & \multicolumn{2}{|c|}{ Nilai rerata $(\mathrm{SB})$} & \multicolumn{2}{|c|}{ Selisih nilai rerata $(\mathrm{SB})$} & \multirow[t]{2}{*}{ Std. error } & \multirow[t]{2}{*}{ IK $95 \%$} & \multirow[t]{2}{*}{ Nilai p } \\
\hline & & 72,8 & $(10,69)$ & & & & & \\
\hline & 4 & 49,5 & $(17,99)$ & 23,3 & $(13,61)$ & 3,21 & $16,51-30,04$ & $<0,001^{*}$ \\
\hline & 4 & 49,5 & $(17,99)$ & & & & & \\
\hline & 8 & 31,1 & $(11,84)$ & 18,4 & $(13,31)$ & 3,14 & $11,77-25,01$ & $<0,001^{*}$ \\
\hline & 0 & 72,8 & $(10,69)$ & & & & & \\
\hline & 8 & 31,1 & $(11,84)$ & 41,7 & $(10,93)$ & 2,58 & $36,23-47,10$ & $<0,001^{*}$ \\
\hline \multirow{6}{*}{$\begin{array}{l}\text { Hiperaktif- } \\
\text { impulsif }\end{array}$} & 0 & 89,4 & $(4,67)$ & & & & & \\
\hline & 4 & 52,8 & $(6,09)$ & 36,6 & $(5,98)$ & 2,68 & $29,17-44,03$ & $<0,001^{*}$ \\
\hline & 4 & 52,8 & $(6,09)$ & & & & & \\
\hline & 8 & 32,6 & $(9,32)$ & 20,2 & $(3,63)$ & 1,62 & $15,69-24,71$ & $<0,001^{*}$ \\
\hline & 0 & 89,4 & $(4,67)$ & & & & & \\
\hline & 8 & 32,6 & $(9,32)$ & 56,8 & $(8,76)$ & 3,92 & $45,93-67,67$ & $<0,001^{*}$ \\
\hline \multirow[t]{6}{*}{ Campuran } & 0 & 73,7 & $(11,72)$ & & & & & \\
\hline & 4 & 50,9 & $(11,67)$ & 22,8 & $(9,97)$ & 2,42 & $17,64-27,89$ & $<0,001^{*}$ \\
\hline & 4 & 50,9 & $(11,67)$ & & & & & \\
\hline & 8 & 31,3 & $(10,75)$ & 19,6 & $(8,83)$ & 2,14 & $15,05-24,13$ & $<0,001^{*}$ \\
\hline & 0 & 73,7 & $(11,72)$ & & & & & \\
\hline & 8 & 31,3 & $(10,75)$ & 42,4 & $(12,87)$ & 3,12 & $35,74-48,97$ & $<0,001^{*}$ \\
\hline
\end{tabular}

* Uji annova, berbeda bermakna pada $\alpha=0,05$

dengan perolehan pada minggu keempat (Tabel 2). Hal ini menunjukkan bahwa perbaikan perilaku di rumah sesudah perlakuan nampak pada semua tipe GPP/H, tetapi perbaikan perilaku pada subjek dengan tipe predominan inatentif lebih banyak terlihat di minggu keempat perlakuan.

Hasil uji normalitas Shapiro Wilk terhadap sebaran data SPPAHI-G menunjukkan pola distribusi normal. Skor total SPPAHI-G sebelum perlakuan menunjukkan rerata 75,3 (SB 11,74) dan sesudah perlakuan 31,5 (SB $10,84)$. Berdasarkan uji statistik didapatkan penurunan skor total SPPAHI-G yang bermakna $(\mathrm{p}<0,001)$, dengan selisih rerata skor sebesar 43,8 (SB 12,35). Dengan demikian, dapat dikatakan bahwa terjadi perbaikan perilaku di sekolah sesudah perlakuan.

Berbeda dengan sebelumnya, pada SPPAHI-G ternyata selisih nilai rerata skor pada kedua sub-skala di minggu ke-8 tidak sebanyak selisih nilai rerata skor yang diperoleh kedua sub-skala pada minggu keempat, meskipun secara statistik didapatkan perbedaan yang bermakna. Dengan kata lain, perbaikan gejala baik perilaku inatensi maupun perilaku hiperaktivitasimpulsivitas di sekolah terjadi lebih banyak terlihat pada minggu ke-4.

Secara umum, nilai rerata skor SPPAHI-G yang didapatkan sesudah perlakuan tidak jauh berbeda antara ketiga kelompok tipe GPP/H subjek, walaupun selisih nilai rerata skor pada minggu ke-8 tidak sebanyak selisih nilai rerata skor yang diperoleh pada minggu ke-4 pada semua kelompok tipe GPP/H subjek (Tabel 3). Nilai rerata skor SPPAHI terbanyak antara sebelum dan sesudah perlakuan adalah pada kelompok subjek tipe predominan hiperaktif-impulsif (Tabel 3). Dengan demikian, dapat dikatakan bahwa sama halnya dengan pengamatan sebelumnya, subjek dengan tipe GPP/H predominan hiperaktif-impulsif lebih banyak mengalami perbaikan perilaku di sekolah. Dari hasil uji normalitas Shapiro Wilk didapatkan bahwa sebaran data SPPAHI-G menunjukkan pola distribusi normal. Selain itu, uji statistik juga menunjukkan perbedaan 
yang tidak bermakna antara rerata skor SPPAHI-O dan SPPAHI-G pada seluruh waktu pengamatan. Artinya, perbaikan perilaku yang terjadi di rumah dan di sekolah memang tidak berbeda di setiap tahap pengamatan. Dengan demikian memang benar terjadi perbaikan perilaku subjek yang tidak dipengaruhi oleh tempat.

\section{Pembahasan}

Pemilihan subjek penelitian dengan salah satu kriteria inklusi anak berusia 6-12 tahun didasarkan pada DSMIV yang menyebutkan kejadian GPP/H sering dijumpai pada anak usia sekolah dasar. ${ }^{17}$ Beberapa anak (14/40) yang bersekolah di Sekolah Khusus Al-Ihsan sudah pernah mengalami fase pendidikan di sekolah umum, tetapi dalam perjalanannya terjadi penolakan dari lingkungan sekolah tersebut sehingga mengharuskan mereka berpindah sekolah.

Berdasarkan karakteristik fisik subjek tidak didapatkan perbedaan nilai rerata antara laki-laki dan subjek perempuan yang meliputi tinggi badan, berat badan, indeks massa tubuh, dan massa lemak tubuh. Hasil yang didapatkan sesuai dengan tahapan perkembangan usia subjek. Pemilihan subjek dengan kriteria inklusi berusia 6-12 tahun didasarkan pada DSM-IV yang menyebutkan kejadian GPP/H sering dijumpai pada anak usia sekolah dasar. ${ }^{17}$ Suatu penelitian epidemiologis oleh Holtkamp $\mathrm{dkk}^{18}$ melaporkan bahwa lebih banyak subjek GPP/H dengan status gizi overweight dan obese. Ternyata, perilaku hiperaktif terkait dengan diagnosis DSM-IV dan tidak berkaitan dengan tingginya tingkat aktivitas fisik yang kemudian berhubungan dengan penurunan risiko terjadinya overweight dan obese pada anak dengan $\mathrm{GPP} / \mathrm{H}$.

Pengukuran tingkat aktivitas fisik tidak menggunakan pengukuran langsung yang lebih obyektif (misalnya akselerometer) dan hanya menggunakan asumsi bahwa aktivitas fisik akan meningkat dengan meningkatnya energi pengeluaran pada anak dengan GPP/H. Dengan demikian, berdasarkan temuan ini, tingkat aktivitas fisik anak GPP/H tidak memberikan efek proteksi apapun sehingga anak terus berkembang menjadi overweight dan obese. Perilaku impulsif adalah salah satu gejala GPP/H, terjadinya gangguan ini berperan anak menjadi obese maupun overweight. Penyebab secara pasti hubungan antara keduanya belum diketahui, tetapi beberapa penelitian terdahulu melaporkan variasi dari reseptor dopamin (DR) yang memengaruhi kedua kondisi tersebut. Pada keadaan obesitas ditemukan gen DRD2 dan DRD4, sedangkan pada GPP/H disebutkan gen DRD2 yang memberikan implikasi pada transmisi neurotransmiter maupun sebagai predisposisi terjadinya keadaan tersebut. Keadaan insufisiensi dopamin yang dimediasi secara alami terkait DRD2 dan berbagai gen dopamin lainnya dengan reward deficiency syndrome, , memicu timbulnya perilaku yang tidak semestinya. Sindrom tersebut berhubungan dengan keadaan obesitas dan GPP/H. Gen DRD4 berkaitan dengan sifat pencarian hal-hal baru, yaitu sifat yang lebih besar dibandingkan perilaku penyalahgunaan zat. Individu dengan variasi genetik DRD2 dan DRD4 akan lebih rentan terhadap kesulitan. Penelitian lain menunjukkan penurunan ketersediaan reseptor DRD2 pada area striatal otak seiring dengan peningkatan indeks massa tubuh. Hal tersebut mendukung pendapat yang menyatakan bahwa perilaku reward seeking berperan pada keadaan obesitas, ${ }^{27}$ setidaknya menunjukkan bahwa gangguan perilaku dapat terlibat pada terjadinya obese maupun overweight.

Latihan SKJ '88 sebagai bentuk perlakuan yang didesain menjadi bagian wajib dari kegiatan sekolah. Kesempatan tersebut tentunya menguntungkan untuk perkenalan bentuk aktivitas fisik pada populasi anak dengan GPP/H di sekolah sekaligus sebagai upaya untuk menjaga kesinambungan pelaksanaan penelitian sehingga dapat mengurangi risiko ketidakpatuhan subjek dari aspek manapun. Mengingat rendahnya motivasi partisipasi anak GPP/H dalam latihan fisik, diperlukan banyak kesempatan agar agar anak-anak GPP/H dapat berpartisipasi dalam latihan fisik untuk meningkatkan kebugaran jasmani dan kemampuan motoriknya.

Latihan SKJ '88 dilakukan setiap hari di sekolah dengan panduan dari seorang instruktur. Pemberian instruksi secara visual lebih besar daripada instruksi verbal, serta dilakukan pengawasan secara konstan saat proses latihan berlangsung. Hal ini telah sesuai dengan pertimbangan khusus pada rekomendasi pelaksanaan latihan fisik untuk anak yang dikeluarkan oleh American College of Sports Medicine (ACSM), bahwa untuk menjamin keamanan pelaksanaan latihan fisik pada anak perlu diberikan instruksi yang tepat dan dilakukan dalam pengawasan. ${ }^{20}$

Selain itu, untuk mengantisipasi kejenuhan yang mungkin terjadi pada subjek dan agar tetap mampu laksana maka latihan SKJ '88 dilakukan dalam 2 sesi latihan, yaitu sebelum masuk sekolah dan sebelum 
pulang ke rumah, dengan masing-masing berdurasi 8 menit 38 detik per sesi latihan. Total waktu latihan SKJ '88 dalam sehari adalah 17 menit 16 detik sehingga sumber energi yang dipakai pada latihan ini sekitar $80 \%$ masih didominasi oleh sumber energi aerobik dan $20 \%$ sisanya anaerobik. ${ }^{21}$

Pada awal penelitian, dilakukan simulasi terlebih dahulu atas segala hal terkait kegiatan ini, baik bagi subjek, orangtua, maupun guru di sekolah. Lagu pengiring SKJ sudah mulai diperdengarkan di sekolah sejak 1 bulan sebelum penelitian dilakukan, untuk melihat respon subjek saat mendengar lagu tersebut. Sejak awal diperdengarkannya lagu pengiring tersebut di sekolah, tidak ada penolakan sedikitpun dari subjek. Begitu pula dengan orangtua subjek yang pada awalnya merasa cemas dan takut terhadap bentuk perlakuan yang diberikan juga akhirnya dapat mengerti, bahkan memberi dukungan kepada anaknya untuk melakukan SKJ '88. Peran serta orangtua ditunjukkan pula dengan mendampingi subjek ke sekolah pada hari Jumat dan bersama-sama melakukan SKJ '88. Sesuai dengan penelitian Cairney $\mathrm{dkk}^{22}$ yang melaporkan bahwa salah satu bentuk tata laksana anak dengan GPP/H adalah menemukan sebuah bentuk aktivitas fisik yang disukai dan mampu terlaksana, dengan gerakan yang dapat dilatih sehingga akan meningkatkan persistensinya terhadap aktivitas tersebut. Harapannya adalah partisipasi anak meningkat seiring dengan proses adaptasi pada semua pihak yang terlibat. Pada akhirmya, terbentuk sebuah kepatuhan untuk melakukan aktivitas fisik tersebut.

Beberapa faktor turut berpengaruh pada kepatuhan subjek melakukan SKJ '88. Sosialisasi pelaksanaan SKJ '88 dirasakan turut memengaruhi kepatuhan subjek. Gerakan SKJ '88 yang sederhana dengan iringan musik yang menyenangkan juga dapat menjadi salah satu faktor ketertarikan subjek melakukan SKJ '88 setiap hari di sekolah, yang bahkan saat ini sudah dapat dilakukan secara mandiri di rumah oleh beberapa subjek. Kemandirian ini sudah mulai nampak pada subjek sejak minggu keempat pelaksanaan SKJ '88. Hal terpenting dan sangat berperan adalah dukungan dari orangtua serta guru yang dengan sabar turut memberikan bimbingan berupa verbal encouragament kepada subjek saat melakukan latihan SKJ '88 sejak periode pengenalan, sehingga subjek menjadi lebih bersemangat dan memiliki motivasi yang tinggi dalam melakukan latihan SKJ'88. Dalam proses latihan ini digunakan modifikasi perilaku pada subjek yang meliputi modelling, prompting, dan reinforcement.

Peran positif latihan fisik didapatkan terhadap perilaku subjek. Perubahan perilaku nampak di dua lingkungan yang berbeda, yaitu di rumah dan di sekolah. Sejalan dengan hasil yang didapatkan Mc Kune $\mathrm{dkk}^{23}$ pada penelitiannya yang juga melaporkan perubahan bermakna pada 4 dari 6 kategori perilaku, berdasarkan skala yang ditetapkan, pada kelompok anak dengan $\mathrm{GPP} / \mathrm{H}$ yang diberikan program latihan fisik intensitas sedang selama 5 minggu. Begitu pula dengan Went ${ }^{24}$ yang melaporkan bahwa terjadi perbaikan konsentrasi pada anak dengan $\mathrm{GPP} / \mathrm{H}$ setelah mereka mengikuti terapi dengan gerakan.

Secara alamiah, seorang anak akan gembira saat bergerak, mempelajari, dan menguasai kemampuan gerak tubuhnya dalam melakukan latihan fisik. Seperti disebutkan oleh Ahmed dan Mohamed, ${ }^{25}$ kemampuan seorang anak dalam melakukan latihan fisik akan memperbaiki persepsi diri dan emosinya sehingga diduga mampu membawa seorang anak dapat berkonsentrasi dan menemukan jalan keluar yang baik saat menghadapi situasi apapun.

Teori yang berkembang saat ini menjelaskan bahwa GPP/H terjadi karena disfungsi neurotransmisi dopaminergik sebagai akibat disregulasi sirkuit yang dimodulasi oleh neurotransmiter dopamin. ${ }^{4}$ Neuron dopamin merupakan komponen penting pada sistem motorik dan ditemukan peningkatan fungsi transporter dopamin (DAT) di neuron presinaptik daerah striatal pada anak dengan $\mathrm{GPP} / \mathrm{H}$, yang kemungkinan telah terjadi perubahan ekspresi gen DAT di korteks prefrontal dan striatal. Akibatnya terjadi peningkatan ambilan kembali dopamin di celah sinaps, yang berdampak pada penurunan konsentrasi neurotransmiter dopamin di celah sinaps sehingga terjadi penurunan neurotransmisi dopaminergik. ${ }^{26}$

Pada beberapa penelitian terdahulu melaporkan bahwa latihan fisik dapat memperbaiki tingkat neurotransmiter/prekursor di dalam darah ${ }^{27,28}$ serta dapat memfasilitasi pemakaian neurotransmiter secara efisien pada sirkuit otak ${ }^{24}$ sehingga dapat memperbaiki fungsi neurofisiologis dan perilaku anak dengan $\mathrm{GPP} / \mathrm{H}$. Hanya saja, bukti yang mempelajari efek latihan fisik pada pelepasan neurotransmiter di otak baru terbatas dilakukan pada binatang percobaan, sedangkan perubahan tingkat neurotransmiter/prekursor di dalam darah tidak selalu mencerminkan perubahan yang terjadi pada otak. ${ }^{23}$

Apabila ditinjau dari hasil penelitian ini, tampak 
perbaikan fungsi kontrol diri dan sistem motorik sehingga subjek lebih mampu melaksanakan tugas sehari-harinya dengan lebih optimal, baik di rumah maupun di sekolah. Perbaikan gejala GPP/H pada subjek dibuktikan dengan penurunan nilai rerata SPPAHI yang diisi berdasarkan hasil pengamatan orangtua dan guru. Perbaikan gejala inatensi ditandai dengan penurunan skala inatensi pada SPPAHI, sedangkan perbaikan gejala hiperaktivitas-impulsivitas ditandai dengan penurunan skala hiperaktivitas-impulsivitas pada SPPAHI. Penurunan nilai rerata SPPAHI, baik hasil pengamatan orangtua maupun guru, sudah tercapai pada 4 minggu pertama sejak perlakuan diberikan kepada subjek, dan terus menurun sampai dengan minggu kedelapan perlakuan.

Gejala inatensi menunjukkan perbaikan yang bermakna, ditandai dengan peningkatan kemampuan subjek memusatkan perhatian, baik di rumah maupun di sekolah. Hal tersebut sesuai dengan laporan orangtua dan guru bahwa subjek mampu memberikan respon yang sesuai terhadap stimulus eksternal, mampu menyelesaikan tugas dan tanggung jawab yang diberikan, termasuk tugas yang membutuhkan kecermatan dalam waktu tertentu.

Gejala hiperaktivitas-impulsivitas juga menunjukkan perbaikan yang bermakna, ditandai dengan peningkatan kemampuan subjek melakukan kontrol terhadap perilaku dan emosinya, baik di rumah maupun di sekolah. Hal tersebut sesuai dengan laporan orangtua dan guru bahwa subjek mampu mengikuti jadwal kegiatan sehari-hari, mampu duduk diam saat mengerjakan tugas yang diberikan, dan mampu lebih tenang saat menghadapi tugas yang sulit. Dengan perbaikan gejala tersebut, perubahan perilaku yang terjadi merupakan gambaran perubahan neurotransmisi dopaminergik di otak yang diduga dapat terjadi pada pemberian latihan SKJ '88 selama 8 minggu. Penelitian terdahulu melaporkan bahwa ditemukan peningkatan dopamin pada otak tikus yang mendapat latihan fisik selama 2 minggu, sebagai bentuk proses adaptasi dari latihan fisik. ${ }^{23}$

Selain itu, dengan sesi latihan SKJ '88 sebanyak 2 kali dalam sehari sangat memungkinkan subjek untuk bertemu dengan teman sebayanya melakukan proses latihan fisik yang sama secara bersama-sama. Dengan demikian, dapat terjadi interaksi sosial yang lebih baik selama proses tersebut berlangsung, mengembangkan sikap toleransi, dan keterikatannya dalam kelompok. Hoza $\mathrm{dkk}^{29}$ melaporkan adanya hubungan antara terbentuknya pertemanan dengan perbaikan perilaku pada anak dengan GPP/H. Sesi latihan SKJ '88 diakui oleh guru menjadi waktu yang paling dinanti oleh subjek, dan tampak antusiasme serta keriangan subjek ketika akan melakukan latihan tersebut. Hal tersebut sejalan dengan Rieber dan Mclaughin ${ }^{30}$ yang melakukan kajian terhadap beberapa teknik manajemen perilaku sebagai salah satu metode penting tata laksana anak dengan GPP/H, salah satunya dengan menggunakan peer interventions. Kami me ngelompokkan siswa saat melaksanakan latihan SKJ '88 dengan teman sebayanya, dan setelah 4 minggu sesudah perlakuan beberapa siswa yang sudah mampu melakukan latihan ini secara mandiri meminta dirinya untuk menjadi instruktur bagi teman-temannya, dengan tetap didampingi oleh instruktur utama. Metode peer tutoring semacam ini, disebutkan oleh Rieber dan McLaughin merupakan sebuah strategi instruksional yang memungkinkan siswa untuk bekerjasama dalam sebuah kegiatan dengan salah satu siswa memberikan bantuan, instruksi, dan umpan balik kepada siswa yang lain. Efek positif yang didapatkan di antaranya adalah perilaku yang membaik dalam menyelesaikan sebuah tugas/tanggung jawab, lebih tenang, dan dapat meningkatkan kinerja akademik. ${ }^{30}$

Dengan demikian, dapat dikatakan bahwa dengan melakukan latihan SKJ '88 secara rutin setiap hari di sekolah, secara tidak langsung me modifikasi perilaku pada subjek dengan menggunakan metode modelling, prompting, dan reinforcement melalui pendekatan peer interventions. Selain itu, yang menarik berdasarkan hasil pengamatan orangtua maupun guru, ditemukan perbaikan perilaku dalam 8 minggu lebih banyak pada subjek dengan tipe predominan hiperaktif-impulsif. Namun dengan temuan ini perlu kajian lebih lanjut mengenai perubahan perilaku pada masing-masing tipe GPP/H setelah menjalani latihan fisik pada periode waktu tertentu.

\section{Daftar pustaka}

1. Miller KJ, Castellanos FX. Attention deficit/hyperactivity disorders. Pediatr Rev 1998;19:373-83.

2. Hechtman L. Attention deficit/hyperactivity disorder. Dalam: Sadock BJ, Sadock VA, editor. Kaplan and Sadock's Comprehensive textbook of psychiatry. Edisi ke-8. Philadelphia: Lippincott Williams \& Wilkins; 2005 h.3183-212.

3. Saputro D. ADHD (attention deficit/hyperactivity 
disorder). Cetakan 1. Jakarta: Sagung Seto; 2009.

4. Kiluk WD, Beden S, Culotta VP. Sport participation and anxiety in children with ADHD. J Attend Disord 2009;12:499-506.

5. Tanjung IS. Prevalensi gangguan pemusatan perhatian/ hiperaktivitas $(\mathrm{GPP} / \mathrm{H})$ pada murid sekolah dasar kelas I-III di wilayah Jakarta Pusat [Tesis]. Jakarta: Departemen Psikiatri FKUI/RSCM; 2002.

6. Delphie B. Pendidikan anak autistik. Edisi 1. Sleman : KTSP; 2009.

7. Furman RA. Attention deficit/hyperactivity disorder : an alternative viewpoint. J Int Child Adolesc Psychiatry 2002;2:125-44.

8. Paternote A, Buitelaar J. ADHD - Attention deficit hyperactivity disorder (gangguan pemusatan perhatian dan hiperaktivitas), tanda-tanda, diagnosis, terapi, serta penanganannya di rumah dan di sekolah. Edisi 1. Jakarta : Prenada; 2010.h.110-120.

9. Witter G. The effect of exercise on hypothalamopituitary-adrenal axis. Dalam: Warren MP, Constantini NW, penyunting. Sports endocrinology. Ottawa: Human Press; 2000.h.43-55.

10. Saputro D. Gangguan hiperkinetik pada anak di DKI Jakarta, penyusunan instrumen baru, penentuan prevalensi, penelitian patofisiologi, dan upaya terapi [Disertasi]. Yogyakarta : Fakultas Kedokteran Universitas Gajah Mada; 2004.

11. Powers SK, Howley ET. Exercise physiology. Theory and application to fitness and performance. Edisi ke-6. Boston: McGraw Hill Companies; 2007.

12. Nieman DC. Physical fitness defined. Dalam: Barrosse E, penyunting. Exercise testing and prescription. Edisi ke-6. Iowa : Mc Graw Hill Companies; 2007.h.30-43.

13. Cahyani N. Latihan fisik untuk anak-anak. In : Indonesia sehat, Indonesia bugar - Seri latihan fisik untuk perempuan dan anak-anak. Jakarta: Balai Penerbit FKUI; 2008.h.34-48.

14. Fleming I, Taylor AJD. The coaching pocketbook. 2004;112. Diakses tanggal 11 Oktober 2011. Didapat dari: http://books.google.com/books?id=IxvnM22IlQCopgis=1 nhttp://skillport.books24x7.com/toc. aspx?bookid $=33983$

15. Retno ES. Perbandingan pengaruh antara latihan senam kesegaran jasmani '84 dengan senam kesegaran jasmani '88 di dalam peningkatan kesegaran jasmani pada siswa putra SMA Theresiana Salatiga tahun ajaran 1988/1989 [Skripsi]. Semarang : FPOK IKIP Semarang; 1989.

16. Suaeb. Pelaksanaan latihan SKJ ' 88 seri I dan seri II pada siswa kelas III SLTP Negeri 132 Jakarta Barat [Skripsi].
Jakarta: FPOK IKIP; 1998.

17. American Psychiatric Association. Diagnostic and statistical manual of mental disorders. Edisi ke-4. Washington DC: American Psychiatric Association; 2000.

18. Holtkamp K, Konrad K, Muller B, Heussen N, Herpertz S, Herpertz-Dahlmann B, dkk. Overweight and obesity in children with attention-deficit/ hyperactivity disorder. Int J Obes 2004; 28:685-89.

19. Altfas JR. Attention-deficit/hyperactivity disorder among adults in obesity treatment. BMC Psychiatry 2002;13:9.

20. Kaplan-Liss E, Renna ME. Exercise in children "Exercise is a family affair". Dalam: Jonas S, Phillips EM, penyunting. ACSM's exercise is medicine : A clinician's guide to exercise prescription. USA : Lippincott Williams \& Wilkin; 2009.h.230-44.

21. Fox EL, Mathews DK. Energy sources. Dalam: Bioenergetics. The physiological basis of physical education and athletics. Edisi ke-4. Philadelphia : Saunders College Publishing;1984.h.12-37.

22. Cairney J, Hay JA, Faught BE, Flouris A. Developmental coordination disorder, self-efficacy toward physical activity and participation in free play and organized activities : does gender matter? Adapted Physical Activity Quarterly 2005;22:67-82.

23. Mc Kune AJ, Pautz J, Lombard J. Behavioral response to exercise in children with attention-deficit hyperactivity disorder. Sports Med 2003;15:17-21.

24. Wendt MS. The effect of an activity program designed with intensive physical exercise on the behaviour of ADHD children. Buffalo : State University of New York; 2000;61:114.

25. Ahmed GM, Mohamed S. Effect of regular aerobic exercises on behavioral, cognitive, and psychological response in patients with attention-deficit/hyperactivity disorder. Life Sci J 2011;8:366-71.

26. Caastellanos FX, Tannock R. Neuroscience of attention-deficit/hyperactivity disorder : The search for endophenotypes. Nat Rev Neurosci 2002;3:617-28.

27. Spencer TJ, Biederman J, Wilens TE, Faraone SV. Novel treatments for attention-deficit/hyperactivity disorder in children. J Clin Psychiatry 2002;63:16-22.

28. Wigal SB, Nemet D, Swanson JM. Cathecolamine response to exercise in children with attention-deficit/ hyperactivity disorder. Pediatr Res 2003; 53:756-61.

29. Hoza B, Mrug S, Pelham WE, Greiner AR, Gnagy EM. A friendship intervention for children with attentiondeficit/hyperactivity disorder : Preliminary findings. J Attenti Dis 2003;6:87-98. 
Listya Tresnanti Mirtha dkk: Pengaruh kepatuhan melakukan latihan SKJ 1988 terhadap GPP/H

30. Reiber C. McLaughlin TF. Classroom interventions: Methods to improve academic performance and classroom behavior for students with attention-deficit/ hyperactivity disorder. Int J Special Edu 2004;19:1-10. 